\title{
An Overlook on Diffusion Mr of Stroke Patients
}

\section{Felçli Hastaların Diffuzyon Mr Sonuçlarına Bir Bakış}

\section{Serkan Koçkanat}

Sivas Numune Hastanesi Acil Servis

\begin{abstract}
Objective: In this study, it is aimed to find out the most affected brain territories of patients who presented to emergency service with ischemic stroke. Materials and Methods: MR results of 75 patients were retrospectively analyzed via computer records. Results: The majority of the patients were female (52\%). Left hemisphere was involved more $54.7 \% \quad(n=41)$. Parietal lobe \%22.8 ( $\mathrm{n}=29)$ was the most affected area. Conclusion: Mostly affected ischemic area of the brain was the parietal lobe whereas the least affected area is the capsule interna. It can be possible to generalize the results if this study is to be expanded to more patients.
\end{abstract}

Key Words: Brain, patient, ischemic stroke

\section{Introduction}

Cerebrovascular event is defined as neurological deficit because of ischemic or haemorrhagic neurological situation. Treatment methods differ depending on the causes. Approximately $87 \%$ of CVE (cerebrovascular event) are ischemic (1). A study based on the data of social security in Turkey between 2008 and 2013 showed that 400.000 people died and 1.5 million people experienced the reults of SVE. Prevalance is $2.2 \%$ (2).

In terms of cerebrovascular events, there are several devices for brain imaging methods like computerized tomograpy, conventional MR and diffusion Weighted MR Imaging (DWI). Magnetic Resonance (MR) imaging aims brain for high contrast resolution in the soft tissue. $1.5 \mathrm{~T}$ and $3 \mathrm{~T}$ devices are used commonly in routine imaging. Best diagnostic method of ischemic infarction is DiffusionWeighted MR which is used throughout the onset of clinical symptoms (4). In DWI, apparent diffusion coefficient (ADC) and fluid attenuation inversion recovery (FLAIR) sequences are used to assess infarction (3). Cytotoxic edema which appears in first six hours of ishemic brain

\section{ÖZET}

Amaç: $\mathrm{Bu}$ çalş̧mada acil servise gelen iskemik inmesi olan hastaların en sık tutulan beyin bçlgelerini bulmak amaçlanmıștır.

Gereç ve Yöntemler: 75 hastanin MR (magnetic resonance) sonuçları retrospektif olarak bilgisayar kayitlarından incelendi.

Bulgular: Hastaların coğunluğu \%52(39) kadındı. Sol hemisfer \% 54.7 ( $\mathrm{n}=41)$ daha çok tutulmuştu. Parietal lob $\% 22.8(n=29)$ en çok tutulan aland.

Sonuc: Beynin en cok iskemik alanı parietal lob iken en az kapsula internaydi. Daha fazla hasta üzerinde çalısmakla bir genellemeye gitmek mümkün olacaktır.

Anahtar Kelimeler: Beyin, hasta, iskemik inme

territory is seen in MR imaging as diffusion restriction. It is shown in DWI series as hyperintense and in ADC series as hypointense (figure1). DWI helps us to find lesion in early hours of ischemic event (5).

\section{Material and Method}

In this study, a radiologist working in a state hospital evaluated the retrospective data by MR. Interpretation of the results by this radiologist was accepted as gold standard. The study involved 75 emergency patients with ischemic stroke as participants. All these patients were hospitalized and treated in neurology service.

Diffusion-weighted MR image used $1.5 \mathrm{~T}$ whole body scanner (SIEMENS) for detecting new ischemic lesions.

Statistical analysis was carried out by using statistical package for social science (SPSS-24). Patients were grouped for gender, age, territory of ischemic stroke and hemisphere of stroke. An error margin of $p<0.05$ was accepted as statistically significant. Ethics committee approval was given by Sivas Health Management. 

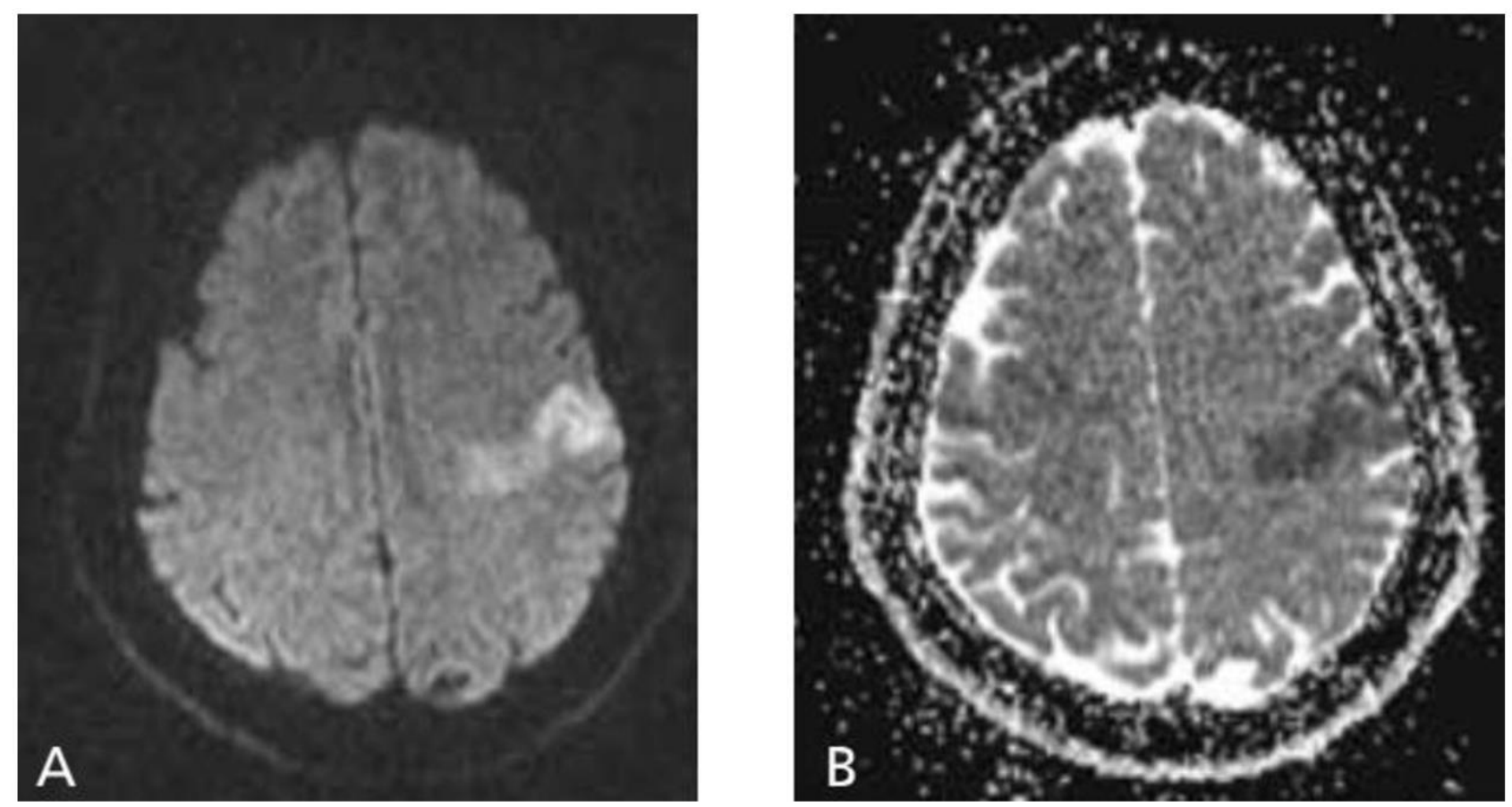

Fig. 1. Picture A show hyperintensity in DAG series, B is hipointensity in ADC (5)

Table 1. Gender

\begin{tabular}{lcc}
\hline & Frequency & Percent \\
\hline Male & 36 & 48.0 \\
Female & 39 & 52.0 \\
Total & 75 & 100.0 \\
\hline
\end{tabular}

\section{Results}

In this study 75 emergency patients with brain infarct lesion were evaluated. 52\%(39) of the patients were female (table 1). According to brain involvement territory, left hemisphere 54.7\%(41) was more affected than right hemisphere(table 2) $(p<0.05)$. Left hemisphere involvement was seen mostly in males (table 3). However, there was no relation between female gender and affected hemisphere territory $(p>0.05)$. The most affected area of the ischemic brain was parietal lobe, the least one was capsula interna. The youngest participant was 32 years old whereas, the oldest one is 91 . The patients were mostly between the ages of 70 and 80 .

Table 2. Affected Hemisphere

\begin{tabular}{lll}
\hline & Frequency & Percent \\
\hline Right & 29 & 38.7 \\
Left & 41 & 54.7 \\
Right and left & 5 & 6.7 \\
Total & 75 & 100.0 \\
\hline
\end{tabular}

There was only one territory involvement in 35 patients. In the rest of patients, there were more than one ischemic territory involvement.

\section{Discussion}

Stroke generally occurs in older age groups. About $70 \%$ of patients with stroke are over 65 years old (12). In the study of Yoneda et al. (6) mean age was found $70 \pm 11$, Kiyan et al. (7) $67.5 \pm 11.8$, Hakbilir et al. (8) $63.5 \pm$ 13.6, Williams et al. (9) $64 \pm 3$, Gürger(10) et al. $68.6 \pm$ 14.6, Reganon et al. (11) $65.3 \pm$ 8.2. In this study mean age (69.1) complied with literature.

In Dubbo's study, there are more male participants than females (13). Appelros et al. evaluated that stroke incidence is at the rate of $33 \%$ with mostly occur in men (14). Divyanshu et al found 59.3\%

Table 3. Hemisphere and Gender

\begin{tabular}{|c|c|c|c|c|}
\hline & Right & Left & Right and left & Total \\
\hline Male & 12 & 23 & 1 & 36 \\
\hline Female & 17 & 18 & 4 & 39 \\
\hline Total & 29 & 41 & 5 & 75 \\
\hline
\end{tabular}


Table 4. Brain Territory

\begin{tabular}{lcc}
\hline Territory of brain infarct & Percent & Frequency \\
\hline Parietal lobe & 22.83 & 29 \\
Occipital & 14.19 & 18 \\
Cerebellum & 11.81 & 15 \\
Frontal & 10.24 & 13 \\
Temporal & 10.24 & 13 \\
Thalamus & 7.09 & 9 \\
Ventricular & 7.09 & 9 \\
Others (bulbus, centrum & 5.51 & 7 \\
semiovale, hypocampus, & & \\
putamen, lentiform nucleus) & & 5 \\
Corona radiata & 3.93 & 4 \\
Pons & 3.14 & 3 \\
Basal ganglion & 2.36 & 2 \\
& & \\
Capsula interna & 1.57 & 127 \\
Total & & \\
\hline
\end{tabular}

Table 5. Cerebral Artery Territory

\begin{tabular}{lcc}
\hline Middle cerebral artery territory & Anterior cerebral artery territory & $\begin{array}{c}\text { Posterior cerebral artery } \\
\text { territory }\end{array}$ \\
\hline Parietal lobe 22.83 & Parietal lobe22.83 & Occipital lobe 14.19 \\
Frontal lobes10.24 & Frontal lobes 10.24 & Temporal lobe 10.24 \\
Temporal lobe 10.24 & & \\
\hline
\end{tabular}

males and $40.7 \%$ females of stroke distribution(15). In this particular study, stroke was more common in females, and this fact shows up as a different conclusion from the formerly-mentioned studies.

Left hemisphere involvement was seen more than in right hemisphere in the study of Tanik (16) et al. Furthermore, there was no relationship between hypertension and involved hemisphere. Yamori et al. found infarction was more involved in the left hemiphere in rats (17). In this study, findings did not differ from other studies.

Middle cerebral artery supplies parietal, frontal lobes and superior part of the temporal lobe. Anterior cerebral artery supplies medial part of parietal and frontal lobes. Posterior cerebral artery supplies occipital lobe and inferior temporal lobe. Divyanshu et al. showed that most ischemic involvement of brain was middle cerebral arterial territory which was $(38.9 \%)$ followed by brainstem $13 \%$, posterior cerebral artery $13 \%$, anterior cerebral artery lesion in $11.1 \%$.

In this study, middle cerebral arterial territory was $\% 43.3$, followed by anterior cerebral artery $(33.07 \%)$, and posterior cerebral artery (24.43\%) (table 5). Middle artery territory involvement ratio is similar to Divyanshu's study. In Yamori et al study anteromedial cortex, occipital cortex, and basal ganglia in rats appear more, while the basal ganglia appear more in humans (17).

The author of this study was pleased to recognize that MR imaging is very important to detect cerebrovascular infarct and its causes. To discover the areas of the brain which are mostly and leastly affected from the brain infarct is crucial for accurate and urgent diagnosis and renovated future treatments. Thus, MR results can lead to significant diagnosis of emergency patients who need to be treated urgently in the first early hours of symptoms of brain involvement territory. It is unfortunate to state that there are not many other options to correctly diagnose the illness.

The author points out that as long as there were limitations to this study such as the number of patients and the limited MR imaging data, it was difficult to generalize the results of this particular study. The following researchers will most 
probably need to have a more expansive sample of participants and a more comprehensive MR imaging data.

\section{References}

1. Writing Group Members, Mozaffarian D, Benjamin EJ, Go AS, Arnett DK, Blaha MJ, et al. Heart Disease and Stroke Statistics-2016 Update: A Report From the American Heart Association. Circulation 2016; 133(4): 38-360.

2. Ozturk Y, Demir C, Gursoy K, Koselerli R. What Factors Influence Survival In Stroke: Turkey Case. Value Health 2015; 18(7): 401402.

3. DeLaPaz RL,Wippold FJ, 2nd, Cornelius RS, Amin-Hanjani S, Angtuaco EJ, Broderick DF, et al. ACR Appropriateness Criteria(R) on cerebrovasculardisease. J Am CollRadiol 2011; 8(8): 532-538.

4. Warach S, Gaa J, Siewert B, Wielopolski P, Edelman RR. Acute human stroke studied by whole brain echo planar diffusion-weighted magnetic resonance imaging. Ann Neurol 1995; 37(2): 231-241.

5. Sade R, Oğul H, Turkısh Radıology Semınar 2016; 4: 198-210.

6. Yoneda Y, Okuda S, Hamada R, Toyota A, Gotoh J, Watanabe M, et al. Hospital cost of ischemic stroke and intracerebral hemorrhage in Japanese stroke centers. HealthPolicy 2005; 73(2): 202-211.

7. Kiyan S, Özsaraç M, Ersel M, Aksay E, Yürüktümen A, Musalar E, Çevrim Ö. Retrospective Analysis of Acute Ischemic stroke patients who attended to the Emergency Department in one year period. JAEM. 2009. 46330

8. Hakbilir O, Çete Y, Göksu E, Akyol C, Kılıçaslan I. Demographic Characteristics of Stroke Population and the Impact of New Emergency
Service Referrals on New Therapeutic Approaches. Turk1sh J EmergMed 2006; 6(3): 132-138.

9. Williams LS, BrunoA, Rouch D, Marriott DJ. Stroke patients' knowledge of stroke. Influence on time topresentation. Stroke 1997; 28(5): 912-915.

10. Gürger M, Bozdemir MN, Yıldız M, Gürger M, Özden,M, Bozgey Z, Dağlı MN. The Role of Cardiac Markers in Determining in Patients Referred to Emergency Service with Ischemic Stroke. Turk J Emerg Med 2008; 8(2): 59-66.

11. Reganon E, Vila V, Martínez-Sales V, Vaya A, Lago A, Alonso P, et al. Association between inflammation and hemostatic markers in atherothrombotic stroke. Thromb Res 2003; 112(4): 217-221.

12. Oğuzhan Ç. Defining in cerebrovascular diseases, classification, epidemiology and risk factors. In: Ö g e AE, editör. Nöroloji. İstanbul: Nobel Tip Kitapevleri 2004; 193-194.

13. Simons LA, Simons J, Friedlander Y, McCallum J. A comparison of risk factors for coronary heart disease and ischaemic stroke: the Dubbo study of Australian elderly. Heart Lung Circ 2009; 18(5): 330-333.

14. Appelros P, Stegmayr B, Terént A. Sex differences in stroke epidemiology. A systematic review. Stroke 2009; 40(4): 10821090.

15. Dubey D, Sawhney A, Kavishwar A, Pande S, Dubey D. A study of anatomical, seasonal and diurnal variation in the occurrence of ischemic stroke. International Journal of Collaborative Research on Internal Medicine \& Public Health 2011; 3(10): 781788.

16. Tanık N, Sarıkaya S, Çelikbilek A, Akyüz Y. Relationship Between Stroke, Hypertension and Brain Hemisphere. BozokMed J 2015; 5(2): 31-34.

17. Yamori $Y$, Horie R, Handa H, Sato M, Fukase M. Pathogenic similarity of strokes in stroke prone spontaneously hypertensive rats and humans. Stroke 1976; 7(1): 46-53. 